\title{
KOMBINASI PENAMBAHAN SUMBER INULIN DAN Lactobacillus $s p$. TERHADAP AKTIVITAS FOSFATASE ALKALIS DAN KETERSEDIAAN ENERGI PADA AYAM KAMPUNG PERSILANGAN
}

(Combination of feeding inulin source and lactobacillus sp. on Alkaline Phosphatase and Metabolizable Energy in Crossbred Local Chicken)

\author{
Yunus, M. ${ }^{1}$, N. Suthama ${ }^{2}$ dan H.I. Wahyuni ${ }^{3}$ \\ 1) Mahasiswa Fakultas Peternakan dan Pertanian Universitas Diponegoro \\ Kampus drh. Soejono Koesoemowardjojo Tembalang Semarang 50275 \\ E-mail : myunus216@gmail.com \\ ${ }^{2,3)}$ Fakultas Peternakan dan Pertanian Universitas Diponegoro \\ Kampus drh. Soejono Koesoemowardjojo Tembalang Semarang 50275 \\ E-mail : nsuthama@yahoo.com
}

Diterima : 17 November 2015

Disetujui : 25 Juni 2016

\begin{abstract}
The research aimed to evaluate the effects of feeding dahlia tuber powder combined with Lactobacillus sp. on alkaline phosphatase activity and metabolizable energy in crossbred lokal chicken. Experimental animal were 168 birds of day old crossbred local chicken (male local chicken cross mating with female layer) fed dahlia tuber powder combined with Lactobacillus sp. at 3 weeks old with initial body weight of $164.45 \pm 2.97 \mathrm{~g}$. The research was assigned in a completely randomized design with $2 \times 3$ factorial pattern. The first factor was 2 levels of dahlia tuber powder, namely 0,8\% (A1) and 1,2\% (A2). The second factor was 3 levels of Lactobacillus sp., namely without Lactobacillus sp. (BO), 1,2 $\mathrm{ml}\left(10^{8} \mathrm{cfu} / \mathrm{ml}(\mathrm{B} 1)\right.$, and 2,4 $\mathrm{ml}\left(10^{8} \mathrm{cfu} / \mathrm{ml}\right.$ (B2) of Lactobacillus sp. Parameters measured were metabolizable energy, alkaline phosphatase activity and daily body weight gain. Data were subjected to F-test and followed by Duncan multiple range test. The result showed that feeding dahlia tuber powder as a source of inulin combined with Lactobacillus sp. significantly $(P<0,05)$ increased the alkaline phosphatase activity and daily body weight gain, but not for metabolizable energy. In conclusion, feeding 1,2\% dahlia tuber powder combined with Lactobacillus sp. at the level of $1,2 \mathrm{ml}\left(10^{8} \mathrm{cfu} / \mathrm{ml}\right)$ is the best combination based on the increase in alkaline phosphatase activity and daily body weight gain of crossbred local chicken.
\end{abstract}

Keywords: crossbred local chicken, body weight gain, inulin, dahlia tuber powder, Lactobacillus sp.

\begin{abstract}
ABSTRAK
Penelitian bertujuan untuk menguji pengaruh pemberian tepung umbi dahlia sebagai sumber inulin yang dikombinasikan dengan Lactobacillus sp. terhadap aktivitas fosfatase alkalis dan ketersediaan energi pada ayam kampung persilangan. Ternak penelitian adalah ayam kampung persilangan (antara ayam kampung jantan dengan ayam petelur betina) umur satu hari sebanyak 168 ekor diberi perlakuan pada umur 3 minggu dengan rerata bobot badan awal $164,45 \pm 2,97 \mathrm{~g}$. Penelitian menggunakan rancangan acak
\end{abstract}


lengkap pola faktorial $2 \times 3$ dengan 4 ulangan. Faktor pertama adalah pemberian dua level tepung umbi dahlia yaitu $0,8 \%$ (A1) dan 1,2\% (A2), sedangkan faktor kedua adalah pemberian tiga level Lactobacillus sp. yaitu tanpa penambahan (B0), 1,2 $\mathrm{ml}\left(10^{8} \mathrm{cfu} / \mathrm{ml}\right)$ (B1), dan $2,4 \mathrm{ml}\left(10^{8} \mathrm{cfu} / \mathrm{ml}\right)$ (B2). Parameter yang diamati adalah energi metabolis, aktivitas fosfatase alkalis dan pertambahan bobot badan harian (PBBH). Data hasil penelitian diuji $\mathrm{F}$ berdasarkan analisis sidik ragam dan jika terdapat pengaruh nyata $(\mathrm{P}<0,05)$ dilanjutkan dengan uji wilayah ganda Duncan. Hasil penelitian menunjukkan bahwa pemberian tepung umbi dahlia sebagai sumber inulin dikombinasikan dengan Lactobacillus sp. memberikan interaksi nyata $(\mathrm{P}<0,05)$ terhadap aktivitas fosfatase alkalis dan pertambahan bobot badan harian $(\mathrm{PBBH})$, tetapi tidak terhadap energi metabolis. Kesimpulan bahwa pemberian tepung umbi dahlia sebagai sumber inulin 1,2\% dan Lactobacillus sp. $1,2 \mathrm{ml}\left(10^{8} \mathrm{cfu} / \mathrm{ml}\right)$ merupakan kombinasi terbaik dilihat dari meningkatnya aktivitas fosfatase alkalis dan pertambahan bobot badan harian (PBBH) pada ayam kampung persilangan.

Kata kunci: ayam kampung persilangan, bobot badan, inulin, tepung umbi dahlia, Lactobacillus sp.

\section{PENDAHULUAN}

Ternak unggas memberikan kontribusi yang sangat besar bagi produksi daging dalam negeri. Kondisi ini dapat dilihat dari data statistik pada tahun 2008, sebanyak 20,3\% produksi daging didominasi dari unggas lokal (Dirjen Peternakan, 2012). Permintaan daging unggas, disatu sisi dari tahun ketahun terus meningkat. Data statistik menunjukkan bahwa permintaan daging unggas pada tahun 2011 adalah sebesar 1,3 juta ton, tahun 2012 sebesar 1,40 juta ton, pada tahun 2013 1,47 juta ton dengan presentase kenaikan sekitar 4,5\% pertahun (Direktorat Jenderal Peternakan dan Kesehatan Hewan, 2013).

Populasi dan produktivitas ayam ras dan ayam lokal perlu ditingkatkan, satu diantaranya adalah dengan pemberian ransum yang berkualitas dan memenuhi kebutuhan. Untuk itu perlu adanya manipulasi ransum guna meningkatkan efisiensi produksi. Manipulasi ransum diharapkan tidak mengganggu asupan nutrien, namun, dapat memaksimalkan efisiensi ransum sesuai dengan kemampuan genetik ayam. Pemberian bahan aditif yang bersifat alami dan tanpa residu dapat dilakukan dalam manipulasi ransum tersebut. Ada beberapa jenis aditif alami yang dapat dimanfaatkan untuk ayam, satu diantaranya adalah kombinasi prebiotik dan probiotik.

Prebiotik adalah bahan aditif yang tidak tercerna oleh sistem pencernaan dan berfungsi untuk media pertumbuhan bakteri bermanfaat atau probiotik, yang selanjutnya dapat berdampak positif pada proses pencernaan. Komponen aditif yang mempunyai sifat prebiotik adalah inulin dan frukto oligosakarida, galakto oligosakarida, dan laktulosa. Kaur et al., (2002) menyatakan bahwa inulin berfungsi sebagai prebiotik, yang banyak terdapat pada umbi dahlia (Dahlia spp. L). Umbi dahlia banyak terdapat di Indonesia dan memiliki kandungan inulin tinggi yaitu 69,50\% $75,48 \%$ (Saryono et al., 1998). Inulin sebagai prebiotik menjadi lebih bermanfaat bagi unggas apabila diberikan bersamaan dengan Lactobacillus sp. sebagai probiotik yang merupakan mikrobia hidup yang diberikan sebagai suplemen pakan. Bakteri tersebut memberikan keuntungan bagi 
induk semang dengan cara memperbaiki keseimbangan populasi mikroba usus.

Sebagaimana yang telah dijelaskan diatas bahwa inulin digunakan sebagai prebiotik karena inulin tidak dapat dicerna dan diserap dalam usus halus, dan termasuk golongan non-digestible karbohidarat dan sejumlah oligosakarida yang dapat menjadi sumber karbohidrat bagi bakteri menguntungkan dalam saluran pencernaan (Crittenden, 1999). Kondisi ini secara tidak langsung dapat mempengaruhi ketersedian energi ransum pada ayam. Indikasi ketersedian energi sangat berkaitan dengan aktivitas fosfatase alkalis (AFA). Rhoads $e t$ al.(1984) menyatakan AFA merupakan enzim, yang dapat menggambarkan adanya peningkatan reaksi karena pemanfaatan energi (Saidu et al., 2005). Tinggi rendahnya proses anabolisme yang terjadi dalam tubuh ditandai oleh meningkatnya AFA (Harper et al., 1979).

Oleh sebab itu, pada penelitian ini dicoba kombinasi inulin umbi dahlia dengan Lactobacillus sp. yang diharapkan dapat bersimbiosis. Penelitian ini bertujuan untuk mengkaji pengaruh dan manfaat penambahan tepung umbi dahlia sebagai sumber inulin yang dikombinasikan dengan Lactobacillus $s p$. terhadap ketersedian energi metabolis, aktivitas fosfatase alkalis dan pertambahan bobot badan harian $(\mathrm{PBBH})$ ayam kampung persilangan. Pemberian kombinasi tepung umbi dahlia sebagai sumber inulin dan Lactobacillus sp. diharapkan bermanfaat bagi inang karena bakteri tersebut mampu memfermentasi serat dari inulin menjadi asam lemak rantai pendek dan menghasilkan asam laktat. Berdasarkan fenomena proses tersebut maka dilakukan penambahan tepung umbi bunga dahlia sebagai sumber inulin dan Lactobacillus sp. pada ayam kampung persilangan, dengan harapan dapat meningkatkan produktivitas / pertambahan bobot badan (PBB) ayam kampung persilangan melalui aspek ketersedian energi metabolis.

\section{MATERI DAN METODE}

\section{Materi}

Materi yang digunakan dalam penelitian adalah ayam kampung persilangan (ayam kampung jantan dengan ayam petelur betina) sebanyak 168 ekor dengan rerata bobot awal 164,45 $22,97 \mathrm{~g}$, dan selama periode adaptasi menggunakan ransum dari pabrikan (AD11). Bahan penyusun ransum yang digunakan yaitu jagung kuning, bekatul, bungkil kedelai, tepung ikan, minyak nabati, $\mathrm{CaCO}_{3}$, mineral, vitamin dan tepung umbi dahlia sebagai sumber inulin serta Lactobacillus $s p$. sesuai dengan perlakuan. Tepung umbi dahlia sebagai sumber inulin diberikan sebanyak $0,8 \%$ dan $1,2 \%$ dari jumlah ransum kemudian dikombinasikan dengan Lactobacillus sp. Ransum perlakuan disusun dengan kandungan protein 19,67\% dan energi metabolis 2.879,55 $\mathrm{kkal} / \mathrm{kg}$ untuk periode starter (3-6 minggu) dan protein $17,73 \%$ dengan energi metabolis $2.879,16 \mathrm{kkal} / \mathrm{kg}$ untuk periode finisher (711 minggu) (Tabel 1). 
Tabel 1. Komposisi dan Kandungan Nutrien Ransum Periode Starter dan Finisher

\begin{tabular}{lcc}
\hline \hline \multicolumn{1}{c}{ Bahan ransum } & Starter & Finisher \\
\hline Jagung Kuning & 53,30 & 54,50 \\
Bekatul & 16,00 & 20,00 \\
Bungkil Kedelai & 19,50 & 15,00 \\
Tepung Ikan & 10,00 & 9,30 \\
CaCO $_{3}$ & 0,70 & 0,70 \\
Vitamin Mineral & 0,50 & 0,50 \\
\hline Total & $\mathbf{1 0 0 , 0 0}$ & $\mathbf{1 0 0 , 0 0}$ \\
\hline Kandungan Nutrien (\%) & & \\
Energi Metabolis (kkal/kg)* & $2.879,55$ & $2.879,16$ \\
Protein Kasar** & 19,67 & 17,73 \\
Lemak Kasar** & 6,42 & 6,35 \\
Serat Kasar** & 6,38 & 6,60 \\
Methionine* & 0,42 & 0,40 \\
Lysine* & 1,95 & 1,06 \\
Kalsium*** & 1,17 & 1,10 \\
Posphor*** & 0,68 & 0,68 \\
\hline Keterangan: & . &
\end{tabular}

Keterangan : *Berdasarkan Tabel Badan Standarisasi Nasional (2006) dan

National Research Council (1994).

**Dianalisis di Laboratorium Ilmu Makanan Ternak Fakultas

Peternakan Universitas Hasanuddin (2014).

****Dianalisis di Laboratorium Ilmu Nutrisi dan Pakan Fakultas

Peternakan dan Pertanian Universitas Diponegoro (2013).

\section{Metode}

Penelitian menggunakan rancangan acak lengkap pola faktorial (RAK) $2 \times 3$ diulang 4 kali masing - masing terdiri dari 7 ekor ayam. Faktor pertama adalah dua level inulin (0,8 \%/A1, 1,2 \%/A2), sedangkan pemberian tiga level bakteri asam laktat Lactobacillus sp. (0 \%/B0, 1,2 $\% / \mathrm{B} 1,2,4$ \%/B2). Kombinasi perlakuan penelitian adalah sebagai berikut:

A1B0 = ransum dengan tepung umbi dahlia sebagai sumber inulin $0,8 \%$ tanpa Lactobacillus sp.

A1B1 = ransum dengan tepung umbi dahlia sebagai sumber inulin $0,8 \%$ dan

1,2 $\mathrm{ml}$ Lactobacillus sp. $\left(10^{8} \mathrm{cfu} /\right.$ $\mathrm{ml})$

A1B2 = ransum dengan tepung umbi dahlia sebagai sumber inulin $0,8 \%$ dan

$2,4 \mathrm{ml}$ Lactobacillus sp. $\left(10^{8} \mathrm{cfu} /\right.$
A2B0 = ransum dengan tepung umbi dahlia sebagai sumber inulin 1,2\% tanpa Lactobacillus sp. A2B1 = ransum dengan tepung umbi dahlia sebagai sumber inulin $1,2 \%$ dan $1,2 \mathrm{ml}$ Lactobacillus sp. $\left(10^{8} \mathrm{cfu} /\right.$ $\mathrm{ml})$

A2B2 = ransum dengan tepung umbi dahlia sebagai sumber inulin $1,2 \%$ dan $2,4 \mathrm{ml}$ Lactobacillus sp. $\left(10^{8} \mathrm{cfu} /\right.$ $\mathrm{ml})$

Pelaksanaan penelitian diawali dengan pembuatan tepung umbi dahlia sebagai sumber inulin dan pembiakan Lactobacillus sp. Umbi bunga dahlia dibersihkan dan dikupas kulit bagian luarnya kemudian diiris tipis dan dijemur selama 3 hari setelah kering di giling sampai menjadi tepung. Bakteri asam laktat Lactobacillus sp. didapat dari Laboratorium $\mathrm{ml})$ 
Mikro Biologi Fakultas Pertanian Universitas Gajah Mada (UGM).

Ayam percobaan dipelihara mulai DOC sampai 20 hari sebagai masa adaptasi pada kandang litter dengan ransum komersil AD11. Periode adaptasi diberikan mulai umur 15-20 hari untuk pemberian terhadap ransum perlakuan secara bertahap hingga diberikan ransum perlakuan sepenuhnya. Selanjutnya pada umur 3 minggu (21 hari) dipindahkan ke kandang individu (baterai) mulai dengan pemberian ransum basal. Ransum dan air minum diberikan ad libitum, pemberian pakan dilakukan 2 kali dalam sehari yakni pagi hari pukul 06.00 WIB dan sore hari pukul 16.00 WIB. Inulin umbi dahlia dan Lactobacillus sp. dicampurkan ke dalam sebagian ransum pada sore hari hingga habis dikonsumsi, kemudian dilanjutkan dengan pemberian ransum tanpa inulin dan Lactobacillus Sp. disertai air minum secara adlibitum. Ayam divaksin ND (Newcastle Disease) pada umur 4 hari dan Gumboro pada umur 13 hari. Lantai kandang disemprot pagi dan sore agar bersih dan nyaman untuk ternak serta kotoran ayam dibersihkan setiap hari.

Pengambilan data dilakukan pada minggu ke 11 pemeliharaan meliputi pengukuran energi metabolis (EM) dengan metode total koleksi dan pengukuran aktivitas fosfatase alkalis dalam darah. Data pertambahan bobot badan harian $(\mathrm{PBBH})$ diperoleh dari penimbangan ayam setiap satu minggu sekali. Pengukuran energi metabolis dengan metode total koleksi digunakan 24 ekor ayam yang dipindahkan ke kandang baterai, kemudian dipuasakan selama 24 jam, dan kembali diberi ransum perlakuan. Ekskreta ditampung dengan menggunakan plastik putih dan ekskreta yang keluar 2 jam sekali disemprot dengan larutan HCL untuk menghindari penguapan nitrogen, ekskreta ditampung selama 72 jam. Ekskreta dikeringkan dengan dijemur di sinar matahari kemudian dihaluskan dan dikomposit untuk dianalisis kandungan gross energi dan pada ekskreta di Laboratorium Ilmu Nutrisi dan Pakan Universitas Diponegoro.

Pengambilan sampel darah diambil dengan menggunakan spuit \pm sampai $3 \mathrm{ml}$ melalui vena jugularis. Darah ayam dimasukan ke dalam tabung reaksi secara perlahan dan dibiarkan beberapa menit sampai membeku, kemudian ditutup dan disimpan dalam termos es. Analisis aktivitas fosfatase alkalis serum darah dilakukan di Balai Laboratorium Kesehatan, Semarang dengan mengunakan alat ABXPentra 400 yang secara otomatis menampilkan datanya.

\section{HASIL DAN PEMBAHASAN}

Pemberian tepung umbi dahlia sebagai sumber inulin dan Lactobacillus sp. sebagai Prebiotik dan Probiotik yang diharapkan terjadi sinbiotik berpengaruh secara nyata $(\mathrm{P}<0,05)$ interaksinya terhadap aktivitas fosfatase alkalis dan pertambahan bobot badan harian ayam kampung persilangan, namun tidak menunjukkan interaksi nyata terhadap energi metabolis (Tabel 2). 
Tabel 2. Rerata Energi Metabolisme, aktifitas fosfatase alkalis dan Pertambahan bobot badan harian Ayam Kampung Persilangan yang diberi perlakuan penambahan kombinasi level inulin dari tepung umbi dahlia dan Lactobacillus sp.

\begin{tabular}{cccc}
\hline \hline \multirow{2}{*}{ Perlakuan } & \multicolumn{3}{c}{ Parameter } \\
\cline { 2 - 4 } & EM & AFA & PBBH \\
\hline & --- Kkal---- & -- U/l--- & $11,72^{\mathrm{b}}$ \\
\hline A1B0 & 2929,33 & $1215,33^{\mathrm{bc}}$ & $12,14^{\mathrm{ab}}$ \\
A1B1 & 2937,47 & $772,33^{\text {cd }}$ & $12,01^{\mathrm{b}}$ \\
A1B2 & 2783,46 & $1787,00^{\text {cd }}$ & $11,65^{\mathrm{b}}$ \\
A2B0 & 3002,87 & $456,33^{\mathrm{d}}$ & $13,22^{\mathrm{a}}$ \\
A2B1 & 2871,38 & $1775,33^{\mathrm{b}}$ & $12,51^{\mathrm{ab}}$ \\
A2B2 & 2802,46 & $2401,33^{\mathrm{a}}$ & \\
\hline
\end{tabular}

${ }^{a, b, c}$ Superskrip yang berbeda pada kolom yang sama menunjukkan perbedaan nyata $(\mathrm{P}<0,05)$.

Energi metabolis yang sebagian besar digunakan untuk hidup pokok pada ternak umumnya, dan berperan penting dalam proses metabolisme tubuh. Berdasarkan Tabel 2, dapat diketahui bahwa ayam kampung persilangan yang diberi tepung umbi dahlia sebagai sumber inulin tanpa Lactobacillus sp. memiliki nilai energi metabolis yang sedikit lebih tinggi, meskipun secara statistik tidak berbeda nyata. Sebaliknya, pemberian tepung umbi dahlia sebagai sumber inulin dan Lactobacillus sp. menunjukkan nilai energi metabolis yang cenderung menurun dan semakin banyak jumlah Lactobacillus sp. yang diberikan energi metabolis semakin rendah. Ini dapat diasumsikan bahwa Lactobacillus sp. dapat dikaitkan dengan perubahan sumber energi seperti glukosa menjadi asam laktat. Le Blay (1999) menyatakan bahwa bakteri asam laktat adalah kelompok bakteri yang mampu mengubah karbohidrat menjadi asam laktat. Namun, pada penelitian ini nilai energi metabolis tidak berbeda nyata menunjukkan bahwa tepung umbi dahlia sebagai sumber inulin yang diberikan sebagai sumber "makanan" bagi Lactobacillus sp. tidak mempengaruhi efektivitas penggunaan sumber-sumber energi.
Asam laktat yang tinggi menyebabkan potensial hidrogen $(\mathrm{pH})$ saluran pencernaan menjadi rendah atau asam dan mikroba lain terutama mikroba coliform atau patogen tidak dapat tumbuh (McNaught dan MacFie, 2000), sehingga yang berkembang lebih baik adalah bakteri asam laktat yang dapat menekan pertumbuhan bakteri patogen. Hal ini didukung dengan penelitian Faradilla (2015) yaitu pemberian tepung umbi dahlia dan Lactobacillus sp. dapat menekan pertumbuhan Escherichia coli dan meningkatkan bakteri asam laktat.

Aktivitas fosfatase alkalis merupakan sebuah gambaran metabolis sel dalam mensintesis bahan intraseluler untuk pertumbuhan dan pembentukan jaringan baru, selain itu, juga merupakan enzim yang dapat menjadi katalisator dalam hidrolisis ester mono fosfat. Apabila dihubungkan dengan pemberian tepung umbi dahlia sebagai prebiotik dapat dimanfaatkan dengan baik oleh Lactobacillus sp. sehingga meningkatkan aktivitas fosfatase alkalis. Namun, bertolak belakang dengan energi metabolis yang menunjukkan tidak ada perbedaan, kondisi ini juga tidak sejalan dengan pendapat Harper et al. (1979) bahwa tinggi rendahnya AFA merupakan indikator bagi 
tinggi rendahnya proses anabolisme yang terjadi dalam tubuh, yang melibatkan $\mathrm{P}$ sebagai komponen energi.

Tepung umbi dahlia sebagai sumber inulin dan merupakan sumber "makanan" bagi Lactobacillus sp. tidak dapat mempengaruhi secara langsung efektivitas penggunaan sumber-sumber energi. Namun, menunjukkan adanya peningkatan retensi $\mathrm{Ca}$, berdasarkan pengamatan yang dilakukan oleh Wirahman (komunikasi personal) secara bersama-sama pada penelitian ini. Secara tidak langsung hal ini berdampak pada peningkatan AFA karena $\mathrm{Ca}$ merupakan aktivator AFA. Hal ini sejalan dengan pernyataan Wes dan Todd (1975) bahwa Ca merupakan aktivator dari beberapa mineral bagi aktivitas enzim fosfatase alkalis.

Perlakuan kombinasi pemberian tepung umbi dahlia sebagai sumber inulin pada level 1,2 \% dan 1,2 ml Lactobacillus sp. (A2B1), menunjukkan hasil $\mathrm{PBBH}$ paling tinggi $(13,22 \mathrm{~g})$ dan berbeda nyata $(\mathrm{P}<0,05)$ terhadap A1B0, A2B0, dan A1B2. Sebaliknya $\mathrm{PBBH}$ terendah dihasilkan oleh pemberian $1,2 \%$ tepung umbi dahlia sebagai sumber inulin tanpa tambahan Lactobacillus sp. (A2B0), dan kombinasi perlakuan lainnya menunjukkan $\mathrm{PBBH}$ medium. Pemberian yang paling tepat dapat diasumsikan pada perlakuan A2B1 karena penambahan Lactobacillus sp. $1,2 \mathrm{ml}$ diikuti dengan jumlah subtrat sebagai sumber "makanan" berupa inulin yang cukup (A2B1) bagi pertumbuhan bakteri asam laktat. Kondisi tersebut dapat meningkatkan pertumbuhan populasi BAL dan menghambat perkembangan bakteri Escherichia coli (Faradilla, 2015). Peningkatan BAL dalam usus berkaitan dengan menurunnya potensial hidrogen $(\mathrm{pH})$, sehingga bakteri patogen tidak dapat berkembang maksimal pada akhirnya saluran pecernaan menjadi sehat. Saluran pencernaan yang sehat sangat memungkinkan villi berkembang dengan baik, sehingga pencernaan dan penyerapan nutrien menjadi lebih tinggi dan berdampak pada peningkatan PBBH. Winarsih (2005), menunjukkan bahwa ayam yang memperoleh probiotik Bacillus sp. dapat meningkatkan luas permukaan usus sehingga nutrien yang terdegradasi lebih sedikit.

Pertambahan bobot badan harian pada penelitian ini (Tabel 2) dengan penambahan tepung umbi dahlia sebagai sumber inulin dan Lactobacillus sp. dapat dimanfaatkan dengan baik. Kondisi ini ditunjukkan dengan peningkatan AFA (Tabel 2) disertai dengan peningkatan asupan protein pada perlakuan A2B1 pengamatan yang dilakukan oleh Wirahman secara bersamasama pada penelitian ini (komunikasi personal), yang merupakan data pendukung untuk produktivitas ayam, meskipun tidak diikuti oleh peningkatan energi metabolis (Tabel 2). Sejalan dengan hasil penelitian Tampubolon et al. (2012) bahwa asupan protein merupakan pendukung pertumbuhan bagi produktivitas (bobot badan) ternak ayam. Selain itu, AFA yang tinggi pada sel menunjukkan adanya pertumbuhan dan pembentukkan sel baru (Bell dan Freeman, 1971), sehingga secara langsung mempengaruhi pertambahan bobot badan pada ayam kampung persilangan yang digunakan pada penelitian ini.

Perlakuan A2B2 menujukkan PBBH yang lebih rendah dibandingkan A2B1, tetapi relatif lebih tinggi dari A2B0. Hal ini diduga karena kelebihan Lactobacillus sp. yang diberikan mengganggu penggunaan nutrien pada inang. Pemberian Lactobacillus sp pada perlakuan A2B2 tampaknya berlebih tanpa diikuti dengan 
pemberian subtrat (inulin) yang memadai, sehingga diduga ketersedian nutrien untuk inang tidak maksimal. Ini sesuai dengan penelitian yang di lakukan oleh Agustina et al. (2007), bahwa pemberian probiotik sebanyak $5 \mathrm{cc} / 1$ air minum) pada ayam broiler cenderung menurunkan performans yang ditunjukkan dengan PBB yang lebih rendah dari perlakuan lainnya yaitu (P0: tanpa probiotik): 250,2 g/ekor/minggu; P1 (2,5 cc/1 air minum): 253,4 g/ekor/minggu dan P2 (5 cc/l air minum): 234,8 g/ekor/minggu). Diduga kelebihan jumlah mikroorganisme dalam saluran pencernaan sangat mungkin terjadi persaingan penggunaan nutrisi dengan inang.

\section{KESIMPULAN DAN SARAN}

\section{Kesimpulan}

Hasil penelitian dapat disimpulkan bahwa pemberian tepung umbi dahlia 1,2\% dan Lactobacillus sp. $1,2 \mathrm{ml}\left(10^{8} \mathrm{cfu} / \mathrm{ml}\right)$ merupakan kombinasi terbaik berdasarkan peningkatan aktivitas fosfatase alkalis dan pertambahan bobot badan harian $(\mathrm{PBBH})$ pada ayam kampung persilangan.

\section{Saran}

Disarankan pemberian tepung umbi dahlia 1,2\% dan Lactobacillus sp. 1,2 ml $\left(10^{8} \mathrm{cfu} / \mathrm{ml}\right)$ yang merupakan kombinasi terbaik, sebagai pakan ayam kampung persilangan, sehingga didapatkan peningkatan aktivitas fosfatase alkalis dan pertambahan bobot badan harian $(\mathrm{PBBH})$ yang optimal.

\section{UCAPAN TERIMA KASIH}

Penulis menyampaikan terima kasih yang tak terhingga pada saudara Irfan Bayu
Wirahman atas bantuannya dalam penyempurnaan data pada penelitian ini.

\section{DAFTAR PUSTAKA}

Agustina, L., S. Purwanti dan D. Zainuddin. 2007. Penggunaan Probiotik (Lactobacillus sp.) Sebagai Imbuhan Pakan Broiler. Seminar Nasional Teknologi Peternakan dan Veteriner. Fakultas Peternakan Universitas Hasanuddin. Makassar.

Bell D.J. and B.M. Freeman, 1971. Physiology and Biochemistry of the Domestic Fowl. Volume 3. Academic Press. London New York.

Crittenden, R.G. 1999. Prebiotics In: Probiotics: A Critical Review. Horizon Scientific Press, Wymondham. Pp. $141-156$.

Direktorat Jenderal Bina Produksi Peternakan, 2012. Statistik Peternakan Tahun 2010. Departemen Pertanian Republik Indonesia, Jakarta.

Direktorat Jenderal Peternakan dan Kesehatan Hewan, 2013. Statistik Peternakan dan Kesehatan Hewan. 2013. Departemen Pertanian Republik Indonesia, Jakarta.

Faradilla, S. 2015. Pemberian Kombinasi Inulin Umbi Dahlia dan Lactobacillus sp. Terhadap Perkembangan Mikroba Usus dan Ketahanan Tubuh Ayam Kampung Persilangan. Tesis. Magister Ilmu Ternak, Fakultas Peternakan dan Pertanian, Universitas Diponegoro. Semarang.

Harper, H., V.M. Rodwell and P.A. Mayes. 1979. Biokimia. Terjemahan dari: 
Harper's Biochemistry. Buku Kedokteran EGC. Jakarta.

Kaur, N. and A.K. Gupta, 2002, Applications of inulin and oligofructose in health and nutrition, J. Biosci. 7:703-714.

Le Blay, G., C. Michel, H. M. Blottiere and C. Cherbut. 1999. Prolonged intake of fructo-oligosaccharides induces a short-term elevation of lactic acidproducing bacteria and a persistent increase in cecal butyrate in rats. $J$. Nutr. 129(12):2231-2235.

McNaught, C.E., dan J. MacFie, 2000. Probiotics in clinical practice: a critical review of the evidence. Int. Dairy J. Nutr. Res. 21: 343-353.

National Research Council. 1994. Nutrient Requirements of Poultry. $9^{\text {th }}$ Revised Edition. National Academy Press. Washington. DC.

Rhoads, D. B., P. C. Thai dan B. D. Davis. 1984. Energy-requiring translocation of the OmpA protein and alkaline phosphatase of Escherichia coli into inner membrane vesicles. J. Bacteriol. 159(1): 63-70.

Saidu, Y., G.A. Alawiyye, I.S. Bilbis and A. Y. Abbas. 2005. Kinetic studies of Rhodanese in some tissues of Sokoto Red Goat. Bull. Sci. Assoc. Nigeria 26: 505-510.

Saryono, P., Z. Sulistyati, A. Delita dan Martna. 1998. Identifikasi jamur pendegradasi inulin pada rizosfir umbi dahlia (Dahlia variabilis). J. Natur. Indon. 11 (1): 22-27.

Tampubolon dan P. P. Bintang. 2012. Pengaruh Imbangan Energi dan Protein Pakan terhadap Energi
Metabolis dan Retensi Nitrogen Ayam Broiler. Jurnal Fakultas Peternakan Universitas

Padjadjaran, Bandung.

West, S. E. and W. Tood. 1975. Text Book of Biochemistry. $3^{\text {rd }}$ Ed. McMillan Company Ltd, New York.

Winarsih, W. 2005. Pengaruh Probiotik dalam Pengendalian Salmonellosis Subklinis pada Ayam: Gambaran Patologis dan Performan. Disertasi. Pascasarjana. Institut Pertanian Bogor. Bogor

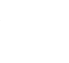

